\title{
The use of natural resources and reproduction of soil fertility in obtaining a given quantity of products
}

\author{
AlexanderAkimenko ${ }^{1, *}$, Nina Masyutenko ${ }^{1}$, and Tatiana Dudkina ${ }^{1}$ \\ ${ }^{1}$ FSBSI «Kursk Federal Agricultural Research Center» 70b, Karl Marx St., Kursk, 305021, Russia
}

\begin{abstract}
The purpose of the study is to determine the suitability for making sound decisions on the reproduction of soil fertility of the following quantitative laws of the methodology for managing material and energy flows in crop rotations: the energy content of 1 ton of humus (in GJ) is equal to half the nitrogen contained in it (in $\mathrm{kg}$ ); the amount of exchangeable energy (in GJ) in $100 \mathrm{~kg}$ of phytomass is equal to the halfsum (in $\mathrm{kg}$ ) of nitrogen and phosphorus pentoxide (about $2 / 3$ of it falls on nitrogen). The approbation was carried out on the data of long-term stationary experiment. The results are as follows: with an increase in the level of fertilizer, nitrogen removal with the yield increased by $30-40 \%$, and that of phosphorus by $6-12 \%$; due to doubling the manure rate and the use of mineral fertilizers, the phosphorus balance became positive, and the nitrogen one remained negative, but improved by $17-28 \%$ depending on the type of a crop rotation. The deviation of the calculated balance of the exchangeable energy from the actual one on the poorly and most richly fertilized backgrounds was -5.5 to $-11.9 \%$ and 3.0 to $8.6 \%$., respectively.
\end{abstract}

Keywords: crop rotation, water, heat, productivity, energy, nitrogen, carbon, humus.

\section{Introduction}

The need to obtain a given amount of field crop production is due to the deepening of the specialization of agricultural enterprises, the establishment of which is limited by the relief of the agricultural landscape, the availability and quality of natural resources necessary for the formation of productivity. Of these, the soil plays a special role, since thanks to it, crops are provided with water, heat (endothermic photosynthesis reaction), mineral and air (up to $70 \%$ ) nutrients. A preventive measure for soil conservation is differentiated use of arable land in crop rotations of various types based on taking into account the degree of erosion hazard in the components of the agricultural landscape and soil-protective capacity of crops, as an integral part of rational nature management in agriculture $[1,2,3]$. Reproduction of soil fertility is also important in connection with the removal of matter and energy with the crop. We have established quantitative relationships and patterns used in the management of material and energy flows in crop rotations [4]. This is the relationship of accumulated energy by crops in connection with the use of water and mineral nutrients.

The purpose of the study is to find out the possibility (suitability) of quantitative relationships used in the management of material and energy flows in crop rotations, for making informed decisions to ensure the reproduction of soil fertility.

\section{Objects and methods}

The approbation was carried out on the data of a long-term (1992-2015) stationary experiment laid down in space and time (all variants simultaneously) in 1991 on typical heavy loamy chernozem with a humus content in the arable layer of 5.2-5.4\% and $\mathrm{pH}_{\mathrm{KCL}} 5.1-5.3$ units. The research was carried out in three crop rotations: cereal-fallow-row crop rotation - I [black fallow - winter wheat (Tritikum vulgare L.) - sugar beet (Beta vulgaris L. v. saccharifera) - silage maize (Zea mays L.) - barley (Hordeum sativum L. )]; green manuring rotation - II [green manured fallow, peas (Pisum sativum L.) - winter wheat (T. vulgare L.) - sugar beet (B. vulgaris L. v. saccharifera) - silage maize ( $Z$. mays L.) - barley (H. sativum L.)]; field crop rotation - III [clover for the 1st cutting (Trifolium arvense L.) - winter wheat (T. vulgare L.) - sugar beet (B. vulgaris L. V. saccharifera) - peas (P. sativum $\mathrm{L}$.) - barley (H. sativum L.)]. The experimental design included the following variants for long-term application of fertilizers: 1 - 6 tons of manure per 1 hectare of crop rotation; 2 - 12 tons of manure $+\mathrm{N}_{37} \mathrm{P}_{37} \mathrm{~K}_{37}$ per 1 ha of crop rotation. The layout of variants was systematic in triplicate tiers. The sown area of the plots was $202.5 \mathrm{~m}^{2}(8.1 \mathrm{~m} \times 25.0 \mathrm{~m})$. The yield was determined by the method of continuous counting. Analyses of soil and plants were carried out in accordance with the state standard, recalculation of natural indicators 
into energy indicators according to generalized reference data [5].

\section{Results and Discussion}

The yield of crops is shown in Table 1. The positive effect of a higher background of fertilization on it appeared after all the predecessors. The highest yield of winter wheat was obtained after black fallow, and the lowest one after a cropped fallow due to the unequal conditions for obtaining timely shoots. Peas turned out to be the best predecessor of barley. The presence of green manured fallow in the crop rotation contributed to an increase in the yield of sugar beet.

Table 1. Crop yield ( $\mathrm{t} / \mathrm{ha}$ ) depending on the place in the crop rotation and the level of fertilizer (average for 1992-2015)

\begin{tabular}{|c|c|c|c|c|c|}
\hline \multicolumn{6}{|c|}{ Crop rotation } \\
\hline \multicolumn{2}{|c|}{ I } & II & & \multicolumn{2}{|l|}{ III } \\
\hline 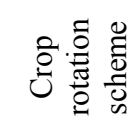 & 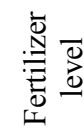 & 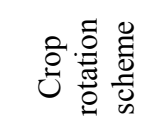 & 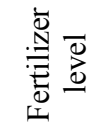 & ? & 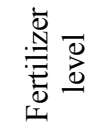 \\
\hline $\begin{array}{l}\text { Black } \\
\text { fallow }\end{array}$ & $=$ & $\begin{array}{l}\text { Green } \\
\text { manure } \\
\text { fallow, } \\
\text { peas }\end{array}$ & $\frac{15.90}{16.70}$ & $\begin{array}{l}\text { Clover for } \\
\text { the } 1^{\text {st }} \\
\text { cutting }\end{array}$ & $\frac{16.2}{17.00}$ \\
\hline $\begin{array}{l}\text { Winter } \\
\text { wheat }\end{array}$ & $\frac{3.67}{4.53}$ & $\begin{array}{l}\text { Winter } \\
\text { wheat }\end{array}$ & $\frac{3.60}{4.35}$ & $\begin{array}{l}\text { Winter } \\
\text { wheat }\end{array}$ & $\frac{3.18}{3.60}$ \\
\hline $\begin{array}{c}\text { Sugar } \\
\text { beet }\end{array}$ & $\underline{35.00}$ & Sugar beet & $\frac{36.60}{42.30}$ & Sugar beet & $\frac{33.60}{37.4}$ \\
\hline $\begin{array}{l}\text { Maize for } \\
\text { silage }\end{array}$ & $\frac{33.10}{37.50}$ & $\begin{array}{l}\text { Maize for } \\
\text { silage }\end{array}$ & $\frac{33.20}{37.00}$ & Peas & $\frac{1.83}{1.94}$ \\
\hline Barley & $\frac{3.22}{3.92}$ & Barley & $\frac{3.41}{3.88}$ & Barley & $\frac{3.68}{4.58}$ \\
\hline
\end{tabular}

Note: 6 tons of manure per 1 ha of crop rotation per year in the numerator; 12 tons of manure $+\mathrm{N}_{37} \mathrm{P}_{37} \mathrm{~K}_{37}$ per 1 ha of crop rotation per year in the denominator.

The composition of crops and differences in yield significantly affected the yield removal of mineral nutrients from the commodity part of the harvest (Table 2).

Their balance against a poorly fertilized background turned out to be negative in all crop rotations. With a doubling of the manure rate in combination with a moderate rate of mineral fertilizers, taking into account the incorporation of by-products into the soil, it was positive for phosphorus and potassium, and remained negative for nitrogen. This is determined by two objective facts: a) the removal of nitrogen with the crop; b) using it to increase productivity and including it in humus.

The content (in GJ) of exchangeable energy (energy equivalent of feed units) in $100 \mathrm{~kg}$ of phytomass is equal to half the sum (in $\mathrm{kg}$ ) of nitrogen and phosphorus pentoxide (about $2 / 3$ of it is nitrogen) [4].

Table 2. Nitrogen and phosphorus balance in the experiment, $\mathrm{kg}$ per 1 ha in a year.

\begin{tabular}{|c|c|c|c|c|}
\hline \multirow{2}{*}{$\begin{array}{c}\text { Crop } \\
\text { rotation }\end{array}$} & $\begin{array}{c}\text { Mineral } \\
\text { elements }\end{array}$ & $\begin{array}{c}\text { Removal with } \\
\text { the } \\
\text { commodity } \\
\text { part of the } \\
\text { harvest }\end{array}$ & Fertilized* & Balance \\
\hline \multirow{2}{*}{ I a } & $\mathrm{N}$ & 66.8 & 6.0 & -60.8 \\
\cline { 2 - 5 } & $\mathrm{P}_{2} \mathrm{O}_{5}$ & 30.9 & 3.0 & -27.9 \\
\hline \multirow{2}{*}{$\mathrm{I} \mathrm{b}$} & $\mathrm{N}$ & 101.0 & 49.0 & -52.0 \\
\cline { 2 - 5 } & $\mathrm{P}_{2} \mathrm{O}_{5}$ & 37.0 & 43.0 & 6.0 \\
\hline \multirow{2}{*}{ II a } & $\mathrm{N}$ & 66.6 & 16.1 & -50.5 \\
\cline { 2 - 5 } & $\mathrm{P}_{2} \mathrm{O}_{5}$ & 28.3 & 9.3 & -19.0 \\
\hline \multirow{2}{*}{ II b } & $\mathrm{N}$ & 100.2 & 60.7 & -39.5 \\
\cline { 2 - 5 } & $\mathrm{P}_{2} \mathrm{O}_{5}$ & 32.7 & 49.7 & 17.0 \\
\hline \multirow{2}{*}{$\mathrm{III} \mathrm{a}$} & $\mathrm{N}$ & 48.4 & 6.0 & -37.4 \\
\cline { 2 - 5 } & $\mathrm{P}_{2} \mathrm{O}_{5}$ & 26.5 & 3.0 & -23.5 \\
\hline \multirow{2}{*}{$\mathrm{III} \mathrm{b}$} & $\mathrm{N}$ & 80.3 & 49.0 & -31.3 \\
\cline { 2 - 5 } & $\mathrm{P}_{2} \mathrm{O}_{5}$ & 29.8 & 43.0 & 13.2 \\
\hline
\end{tabular}

* Note: including the weight of green manure crop: a represents 6 tons of manure; $b$ represents 12 tons of manure $+\mathrm{N}_{37} \mathrm{P}_{37} \mathrm{~K}_{37}$ per 1 ha of crop rotation; I represents cereal-fallow-row crop rotation; II represents green manuring crop rotation; III represents field crop rotation.

In the commodity part of cereals and oilseed crops, the exchangeable energy is 4-6 times higher in comparison with the by-product; the entire yield is removed from fodder crops. The results of comparing the estimated and actual balance of exchangeable energy are presented in Table 3.

Table 3. Balance of nitrogen and phosphorus in the experiment, $\mathrm{kg}$ per 1 ha of crop rotation per year.

\begin{tabular}{|c|c|c|c|c|c|}
\hline \multirow{2}{*}{$\begin{array}{c}\text { Crop } \\
\text { rotation }\end{array}$} & \multirow{2}{*}{$\begin{array}{c}\text { Land } \\
\text { content }\end{array}$} & $\begin{array}{c}\text { Return with } \\
\text { non- } \\
\text { commodity } \\
\text { part }\end{array}$ & \multicolumn{2}{|c|}{ Balance } & \multirow{2}{*}{$\frac{R-F}{R} \times 100}$, \\
\cline { 4 - 5 } & & $\mathrm{R}$ & $\mathrm{F}$ & \\
\hline I a & 64.8 & 10.1 & -48.9 & -54.7 & -11.9 \\
\hline I b & 76.5 & 12.8 & -69.0 & -63.7 & 7.7 \\
\hline II a & 62.6 & 11.0 & -47.5 & -51.6 & -8.6 \\
\hline II b & 75.6 & 13.6 & -66.5 & -62.0 & 6.8 \\
\hline III a & 53.4 & 11.2 & -40.0 & -42.2 & -5.5 \\
\hline III b & 60.6 & 12.0 & -50.1 & -48.6 & 3.0 \\
\hline
\end{tabular}

Note: $a$ represents 6 tons of manure, $b$ represents 12 tons of manure $+\mathrm{N}_{37} \mathrm{P}_{37} \mathrm{~K}_{37}$ per 1 ha of crop rotation, $R$ represents estimated balance, $F$ represents actual balance by the removal of $\mathrm{N}$ and $\mathrm{P}_{2} \mathrm{O}_{5}$. Designations of crop rotations are the same as in Table 2.

The negative balance of nitrogen and the associated negative balance of exchange energy predetermine the negative balance of humus. Table 4 shows the results of 
comparing the productivity of crop rotations with the balance of humus, depending on the norms of nitrogen according to scientific publications over the past 6 years. It can be seen from them that as nitrogen in the composition of fertilizers increases, simultaneously with an increase in the productivity of arable land, the consumption of humus decreases and even its balance with a zero difference is ensured, similar to the positive effect of the expansion of the proportion of perennial grasses capable of symbiotic nitrogen fixation in crop rotations. At the same time, a negative balance of humus in the soil and a decrease in the level of productivity are evidence of a decrease in soil fertility.

Table 4. Crop rotation productivity due to nitrogen rates and humus balance, per 1 ha per year.

\begin{tabular}{|c|c|c|}
\hline $\begin{array}{c}\text { Nitrogen } \\
\text { applied*, } \\
\text { kg / ha }\end{array}$ & $\begin{array}{l}\text { Humus balance, } \\
\text { GJ / ha }\end{array}$ & $\begin{array}{c}\text { Arable land } \\
\text { productivity, } \\
\text { GJ / ha }\end{array}$ \\
\hline \multicolumn{3}{|c|}{ Cereals $50 \%$, row crops $50 \%$} \\
\hline 64 & -28.9 & 79.9 \\
\hline 135 & 11.5 & 102.0 \\
\hline \multicolumn{3}{|c|}{ Cereals $60 \%$, row crops $40 \%$} \\
\hline 0 & -33.1 & 44.9 \\
\hline 40 & -23.5 & 54.5 \\
\hline 160 & 6.5 & 86.1 \\
\hline \multicolumn{3}{|c|}{$\begin{array}{l}\text { Cereals with maize (Z. mays L.) } 70 \% \text {, alfalfa (Medicago } \\
\text { sativa L.) } 20 \% \text {, sunflower (Helianthus annus L.) } 10 \%\end{array}$} \\
\hline 0 & -9.2 & 24.6 \\
\hline 84 & 1.5 & 41.4 \\
\hline \multicolumn{3}{|c|}{$\begin{array}{c}\text { Cereals with maize (Z. mays L.) } 64 \% \text {, row crops and alfalfa } \\
\text { (M. sativa L.) } 18 \% \text { each }\end{array}$} \\
\hline 0 & -19.4 & 45.3 \\
\hline 79 & -16.1 & 61.2 \\
\hline 158 & 2.8 & 80.3 \\
\hline \multicolumn{3}{|c|}{ Cereals $40 \%$, row crops $60 \%$} \\
\hline 0 & -19.8 & 30.6 \\
\hline 60 & -14.4 & 42.6 \\
\hline
\end{tabular}

Note: * with mineral fertilizers and farm manure.

Achievement of high productivity of arable land due to the composition and alternation of crops leads to an increase in the consumption of soil fertility. If the latter is not reproduced, then the positive effect of crop rotation decreases over time. The negative consequences of nonobservance of the law of return are supplemented by the underutilization of the warm period, the useless loss of water and carbon dioxide from the open surface, which is clearly demonstrated by the example of our experiment (Fig. 1).

Thus, a smaller decrease in the productivity of the crop rotation with green manure fallow in comparison with cereal-row crop rotation is due to the application of green fertilizer and is ensured due to the more complete use of natural resources. The smallest difference in the experience in connection with the level of fertilization is due to the significantly lower removal of matter and energy in the crop rotation.

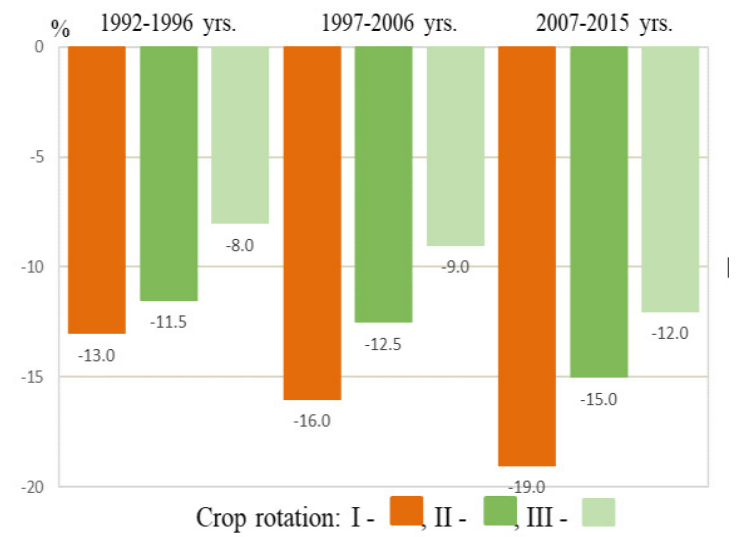

Fig 1. The decrease in time (\%) of arable land productivity against a poorly fertilized background (6 tons of manure) relative to the most fertilized (12 tons of manure $+\mathrm{N}_{37} \mathrm{P}_{37} \mathrm{~K}_{37}$ per 1 ha of crop rotation).

The energy content of 1 ton of humus (in GJ) is equal to half the nitrogen content in it (in $\mathrm{kg}$ ) $[4,5]$. This suggests the possibility of taking measures to stabilize the humus content on the basis of ensuring a deficit-free nitrogen balance. Table 5 shows a comparison of the nitrogen balance in the experiment with the actual and estimated humus balance. The latter was determined by dividing the nitrogen balance (in $\mathrm{kg}$ ) into the nitrogen content in 1 ton of humus (in the soil of the experimental plot, $46 \mathrm{~kg}$ per 1 ton of humus). Experimentally found humus balance in all the variants was negative, and its absolute values (except for the crop rotation with green manured fallow) exceeded the calculated ones.

Table 5. Comparison of the actual and estimated balance of humus, t per 1 ha per year.

\begin{tabular}{|c|c|c|c|}
\hline Crop rotation & $\mathrm{F}$ & $\mathrm{R}$ & $\frac{R-F}{R} \times 100, \%$ \\
\hline I a & -1.61 & -1.32 & 18.0 \\
\hline I b & -1.34 & -1.13 & 15.7 \\
\hline II a & -0.93 & -1.10 & -18.3 \\
\hline II b & -0.69 & -0.86 & -24.6 \\
\hline III a & -1.15 & -1.05 & 8.7 \\
\hline III b & -0.99 & -0.68 & 31.3 \\
\hline
\end{tabular}

Note: $F$ represents actual balance of humus, $\mathrm{t} /$ ha per year; $R$ represents estimated value of humus balance, $\mathrm{t}$ per ha per year, $a$ represents 6 tons of manure, $b$ represents 12 tons of manure $+\mathrm{N}_{37} \mathrm{P}_{37} \mathrm{~K}_{37}$ per 1 ha of crop rotation.

These discrepancies are primarily explained by the fact that the calculations did not take into account carbon, which is an important structure-forming element of humus. It is difficult to balance carbon due to the fact that the 
primary processes of photosynthesis use carbon dioxide released from the soil both in the course of microbiological activity and again as a result of the "respiration" of the roots. To a large extent, the reserves of soil carbon, depending primarily on the type of soil [6], are associated with its removal with the harvest [7], which, to varying degrees, is associated with the loss of nitrogen $[8,9]$.

In our experiment the calculated removal of carbon with a commercial part in cereal-fallow-row crop, field, and green manuring crop rotations was, respectively, 3.0, 2.6 and 1.5 times less in comparison with its input with byproducts, manure and green manure.

Determination of soil organic carbon content and its quality in the fifth rotation cycle of our stationary experiment indicates an increasing positive effect of fertilizers against the background of the application of byproducts in the sequence of $12 \mathrm{t} /$ ha manure $+\mathrm{N}_{37} \mathrm{P}_{37} \mathrm{~K}_{37}$, $12 \mathrm{t} /$ ha manure $+\mathrm{N}_{37} \mathrm{P}_{37} \mathrm{~K}_{37}+$ green manure, which, to a certain extent, reflects the difference in the actual balance of humus and the positive effect of green fertilization on it.

The return of nitrogen commensurable with the removal of exchangeable energy is important in terms of carbon sequestration by crops and its retention in humus, which can make a certain contribution to mitigating the effects of global warming [7, 10]. The need for nitrogen during plant ontogenesis is due to both its inclusion in the composition of energy-containing structures and its localization in tissues and organs. The development of the leaf surface with an improvement in nitrogen nutrition contributes not only to an increase in photosynthesis coupled with transpiration, but also allows a more complete use of carbon dioxide released from the soil due to the location of stomata on the back of the leaf. The role of such a screen in crop rotations saturated with shortseason crops is performed by catch crops, the use of which for green fertilization not only prevents the loss of resources, but also contributes to the reproduction of soil fertility [11].

The unequal possibility for predicting nitrogen and carbon balances is predetermined by the peculiarity of their circulation in the agrocenosis. Carbon entering the soil as part of organic fertilizers (manure, green manure) and noncommercial part of the crop after mineralization is partially used to create biomass of short-lived microorganisms and can be partially included (together with organic nitrogen) in subsurface processes, but its predominant part is released from the soil, uselessly lost in the atmosphere, or provides air nutrition for crops. The nitrogen regime of the soil is completely controlled by soil microorganisms, the flows of nitrogen through the cells of which exceed its consumption by field crops. The nitrogen of mineral fertilizers accelerates the mineralization of organic matter, which contributes to the accumulation of mobile nitrogen in the soil. At the same time, with a better carbon supply, microorganisms absorb more ammonium and amino acids, and more immobilized nitrogen is accumulated in the soil $[12,13]$. The afore mentioned causes significantly less (in comparison with carbon) unproductive nitrogen losses associated mainly with the processes of nitrification and denitrification.

\section{Conclusion}

Thus, as a result of the studies performed to analyze the results obtained in the stationary field experiment for the period of 1992-2015, the possibility of using quantitative relationships employed in the management of material and energy flows in crop rotations for making informed decisions on the production of soil fertility was revealed.

Achieving high productivity of arable land due to the composition and alternation of crops leads to a decrease in soil fertility. The negative consequences of noncompliance with the law of return are intensified by the underutilization of the possibilities of natural resources (warm period, loss of water, $\mathrm{CO} 2$ from the soil, the presence of periods with the absence of plants on the soil, etc.). To stabilize the humus content in the soil, it is important to ensure a deficit-free humus balance, while half of it must enter the soil in an organically bound form.

To substantiate decisions on the reproduction of soil fertility when obtaining a given (respectively, permissible from the standpoint of adaptive-landscape land use specialization of agricultural enterprises) amount of field crop production, the following is fundamentally important: the need for fertilizers for nitrogen and phosphorus must be commensurated with the removal of exchangeable energy with the commodity part of the harvest; the degree of nitrogen return with a probability of up to $70 \%$ reflects the dynamics of humus; the inclusion of catch crops in crop rotations as green manure helps to reduce the unproductive use of water and carbon dioxide resources.

The work was carried out within the framework of the state assignment of Kursk Federal Agricultural Research Center, topic No. 0632-2019-0013.

\section{References}

1. S. Dubey, A. Sharma, V.K. Panchariya, M.K. Goyal, R.Y. Surampalli, T.C. Zhang, Ecol. Indic. 127107768 (2021)

2. I.A. Trofimov, L.S. Trofimova, E.P. Yakovleva, O.S. Oparina, M.L Oparin, Biol. Bull. 46 1442-1447 (2019)

3. C. Paul, A.-K. Techen, J.S. Robinson, K. Helming, J. Cleaner Prod. 227 1054-1067 (2019)

4. A.S. Akimenko, Zemled. 5 7-10 (2019)

5. V.M. Volodin, Ecological principles for the assessment and use of soil fertility, 336 (2000)

6. V.M. Semenov, N.B. Zinyakova, T.N. Lebedeva, A.S. Tulina, B.M. Kogut, L.S. Malyukova, Euras. Soil Sci., $51434-447$ (2018) 
7. A. Poyda, H.-D. Wizemann, J. Ingwersen, R. Eshonkulov, P. Högy, M.S. Demyan, P. Kremer, V. Wulfmeyer, T. Streck, Agric., Ecosyst. \& Environ, 276 31-46 (2019)

8. V.A. Velichko, O.V. Demidenko, Agr. Sci. \& Pract., 2 35-49 (2015)

9. O.V. Demydenko, V.A. Velychko, Agr. Sci. \& Pract., 6 28-40 (2019)

10. E.I. Teixeira, J. Ruiter, A.-G. Ausseil, A. Daigneault, P. Johnstone, A. Holmes, A. Tait, F. Ewert, Sci. Tot. Env. 616-617, 785-795 (2018)

11. A.A. Mana, A. Allouhi, K. Ouazzani, A. Jamil, J. Cleaner Prod. 295, 126293 (2021)

12. A.M. Semenov, I.L. Khvatov, A.V. Olenin, Current Invest. Agr. \& Current Res., 6 (2) 715 (2019)

13. C.S. Pollet, L.S. Silva, B. Chaves, L.R. Neto, M.F. Dossin, S.J. Giacomini, A.C. Filho, Soil Sci. 4904 (2019) 